\title{
DEVELOPING PERSONAL COMPETENCY TEST INSTRUMENT IN IDENTIFYING THE ATTITUDE OF RADICALISM
}

\author{
Rahmat Syah $^{1}$, Lusiana ${ }^{2}$ \\ ${ }^{1,2}$ Institut Bisnis dan Multimedia Asmi, Jakarta, Indonesia \\ ${ }^{1}$ rahmat29syah@gmail.com, ${ }^{2}$ lusiana@ibmasmi.ac.id
}

\begin{abstract}
The era of globalization of radicalism develops rapidly, especially through the social networks accessed by high school students and university students. Thus, it is necessary to measure students' radicalism attitudes to know the description of students' characters so that the institution can take prevention or coaching actions. This study aimed to develop a college entrance test instrument, especially the entrance test at IBM ASMI. The developed instrument was the Personal Characteristics Test (TKP) instrument which could identify radicalism. The research method was $R$ \& D development research with qualitative and quantitative approaches. The content of the instrument was validated through the experts judgment and proven by construct validity by conformatory analysis and proven reliability. The results of this study was a valid and reliable measurement instrument that could identify radicalism for students. There were 5 dimensions of radicalism, starting from religion, family, personality, political views, and social relations. Focus Group Discussion produced 5 dimensions, 13 indicators, and 35 items that could be used to measure students' radicalism attitudes. The results of the validity test contained 2 items that needed to be improved. The results of the reliability of the instruments developed were high and the instrument was ready to use.
\end{abstract}

Keywords: test instrument, personality competence, attitude of radicalism, religion

\section{PENGEMBANGAN INSTRUMEN TES KOMPETENSI KEPRIBADIAN DALAM MENGIDENTIFIKASI SIKAP RADIKALISME}

\begin{abstract}
ABSTRAK
Era globalisasi radikalisme berkembang dengan pesatnya, khususnya melalui jejarang sosial yang digunakan oleh Siswa Menengah Atas dan Mahasiswa. Perlunya pengukuran sikap radikalisme mahasiswa untuk mengetahui gambaran karakter dari mahasiswa agar pihak institusi dapat melakukan pencegahan atau pembinaan. Penelitian ini bertujuan untuk mengambangkan instrumen tes masuk perguruan tinggi khususnya tes masuk di IBM asmi. Instrumen yang dikembangkan adalah instrumen Tes Kompetensi Pribadi (TKP) yang dapat mengidentifikasi sikap radikalisme. Metode penelitian menggunakan penelitian pengembangan R \& D dengan pendekatan kualitatif dan kuantitatif. Instrumen yang dikembangkan dibuktikan validitasnya secara isi dengan expert judgement dari para ahli pengukuran dan dibuktikan dengan validitas konstruk dengan analisis konformatori serta dilakukan pembuktian reliabilitas. Hasil penelitian ini yaitu instrumen pengukuran sikap radikalisme valid dan reliabel serta dapat mengidentifikasi sikap radikalisme untuk mahasiswa. Terdapat 5 dimensi sikap radikalisme dari mulai agama, keluarga, kepribadian, pandangan politik dan relasi sosial. Focus Group Discussion menghasilkan 5 dimensi dan 13 indikator serta 35 butir item yang dapat digunakan untuk pengukuran sikap radikalisme mahasiswa. Hasil uji validitas terdapat 2 item yang perlu diperbaiki. Hasil reliabilitas pada instrumen yang dikembangkan tergolong tinggi dan instrumen siap digunakan. Kesimpulan dalam pengembangan instrumen radikal pada penelitian ini yaitu terkonstruksinya sikap radikal pada penelitian ini digambarkan dalam lima dimensi pertama agama, keluarga, kepribadian, pandangan politik dan relasi sosial.
\end{abstract}

Kata Kunci: instrumen tes, kompetensi kepribadian, sikap radikalisme, agama

\begin{tabular}{|c|c|c|}
\hline Submitted & Accepted & Published \\
\hline 27 November 2020 & 03 Maret 2021 & 27 Maret 2021 \\
\hline
\end{tabular}

\begin{tabular}{|l|l|l|l|l}
\hline Citation & $:$ & Syah, R., \& Lusiana. (2021). Developing Personal Competency Test Instrument in Identifying the Attitude of Radicalism.
\end{tabular} Jurnal PAJAR (Pendidikan dan Pengajaran), 5(2), 337-348. DOI : http://dx.doi.org/10.33578/pjr.v5i2.8222.

\section{PENDAHULUAN}

Tes karakter pribadi telah terbukti dapat memprediksi kemampuan individu dalam bidang soft-skill (Verbeke, 1994) (Verbeke, 1994). Pengukuran karakter kepribadian sangat diperlukan oleh masyarakat Indonesia dalam memerangi kasus kekerasan, pelecehan, pergaulan bebas, narkoba dan radikalisme kedepannya BPS, BKKBN, Kemenkes, (2012) 
menggambarkan bahwa kasus kekerasan, pelecehan, pergaulan bebas, narkoba dan radikalisme di Indonesia masih tergolong tinggi. Salah satu dari masalah tersebut yang perlu untuk diukur adalah potensi sikap radikalisme, radikaslisme dapat mengganggu karekter bangsa yaitu Pancasila. Radikalisme saat ini dikenal dengan ciri penggunaan kekerasan atas nama agama atau ideologi lainnya. Kekerasan tersebut dapat berupa hasutan, fisik atau verbal. Yang paling disorot adalah agama menjadi motivasi dan ideologi untuk membangun negara beraliran tertentu di tengah masyarakat demokrasi (Ghosh et al., 2017). Radikalisme merupakan ancaman cukup serius yang terjadi atas dasar agama terkait dengan politik dan situasi keamanan.

Selain itu, penyebab aksi teror akibat dari radikalisme tersebut terjadi karena beberapa faktor. Menurut survey dari BNPT yang dikutip dari BBC NEWS Indonesia (2018) faktor pertama yang menjadi penyebab radikalisme yaitu pemahaman keagamaan yang keliru sebanyak 45 persen, kedua; solidaritas komunal sebanyak 20 persen, ketiga; mental atau mudahnya masyarakat terhasut berita bohong sebanyak 12,7 persen, keempat; dendam sebesar 10,9 persen, kesenjangan dan ketidakadilan sosial dengan persentase 9,1 persen dan kelima; separatisme sebesar 1,8 persen. Dari faktor-faktor tersebut diketahui bahwa pemahaman agama yang keliru menjadi persentase yang terbesar. Sehingga dapat dipastikan para pelaku teror tidak memiliki rasa toleransi dalam beragama.

Gejala intoleransi berkembang pesat dengan adanya kemajuan teknologi informasi melalui internet, dalam hal ini media sosial. Para ekstrimis dengan leluasa dapat menyebarkan paham dan ajaran agama dengan jalan kekerasan serta ujaran kebencian secara online, sehingga intoleransi agama berkembang dengan pesatnya menjadi akar dari ekstrimisme, radikalisme sampai dengan kearah kekerasan seperti prilaku teror (Conway, 2017). Internet memiliki aturan main tersendiri bagi ekstrimis dan terorisme untuk merekrut serta mempengaruhi calon kader kelompok agamis garis keras tersebut (Honig \& Yahel, 2017). Sebagai contoh di Indonesia seorang pedagang bakso AW menjadi tersangka perakit bom panci di Bandung, diketahui AW terpengaruh oleh ajakan di media sosial (Wirawan, 2017).

Sikap radikal sudah ada sejak peradaban manusia berkembang, radikalisme muncul akibat dari banyak faktor baik internal maupun eksternal, cikal bakal radikalisme munculnya adalah perebutan kekuasaan di banyak negara. Berbagai pakar menganggap perbedaan pandangan agama sebagai salah satu penyebab munculnya radikalisme agama yang mana satu pihak menginginkan penerapan agama dalam aspek seluruh aspek kehidupan masyarakat sampai ke akarnya. Kelompok-kelompok paham radikalisme ini kurang bisa menerima adanya perbedaan. Dalam konteks agama islam sendiri diajarkan bahwa perbedaan seharusnya dijadikan sebagai warna dalam kehidupan, sekaligus keindahan.

Radikalisme adalah prilaku memiliki kecendrungan untuk terlibat kekerasan atau peperangan demi membela idealisme. Sebagai fenomenologi, radikalisme harus dikaitkan dengan filosofis atau teologis dan orientasi politik (Nurish, 2020). Sementara Amin (2008) menjelaskan bahwa radikalisme adalah upaya sistematis yang dilakukan individu atau kelompok untuk melakukan perubahan radikal sampai ke akar-akarnya dengan kekerasa. Sehingga dapat disimpulkan radikalisme pada pengertian ini merujuk kepada radikalisme prilaku yang mengarah ke kerasan demi idealism agama.

Radikalisme saat ini tidak hanya menyasar pada individu yang memiliki Pendidikan rendah saja bahkan terdapat berbagai kasus radikalisme terlahir dari pendidikan tinggi. Hal tersebut dibuktikan dengan bergabungnya mahasiswa pasca sarjana kedokteran UGM pada kelompok radikal ISIS. Mahasiswa sebagai agen perubahan kiranya menjadi sasaran para organisasi radikal agar menambah kekuatan radikalisme dalam dunia akademis, sehingga para akademisi yang terpapar oleh ideologi radikal menjadi ajang promosi bagi kelompok radikalis untuk mempengaruhi lainnya. Dalam konteks indonesia, perbedaan dan keberagaman sudah merupakan konteks yang wajar dan lumrah. 
Secara geografis, yang menjadikan bangsa memiliki perbedaan ras dan suku. Secara sosiologis pun kehidupan mengajarkan sikap toleransi. Karena itu, jangan sampai keberagamann perbedaan diusak oleh virus-virus paham radikalisme.

Di dunia kampus sendiri proses perkuliahan masih dirundung persoalan intoleransi dan radikalisme. Berdasarkan penelusuran Noorhaidi Hasan (2012), pintu masuk gerakan radikalisme di Indonesia itu adalah perguruan tinggi. Sejak tahun 1980-an banyak alumni Timur Tengah yang mendapatkan beasiswa dari Saudi (LPIA) pulang ke Indonesia. Awalnya kebanyakan dari mereka adalah kader Dewan Dakwah Islamiyah Indonesia (DDII), namun sekembalinya dari Timur Tengah mereka kemudian menandai kelahiran generasi Islam salafism baru di Indonesia. Mereka memang kader-kader DDII, tetapi bagaimanapun mereka berbeda dengan generasi DDII era sebelumnya. Kebanyakan mereka sudah memiliki komitmen untuk menyebarkan ajaran salfism.

Dari fakta yang ada radikalisme bisa masuk kesiapa saja tidak hanya kelompok masyarakat miskin tapi radikalisme juga bisa masuk ke kelompok intelektual. Oleh sebab itu perlu adanya pengembangan suatu alat ukur yang valid dan reliabel dalam mengukur karakter pribadi individu khususnya mahasiswa, sehingga pihak pemerintah dan berbagai lembaga Pendidikan tinggi yang terkait dapat bersamasama melakukan tindakan preventing. Tujuan penelitian ini adalah untuk mengkonstruksikan sikap radikalisme mahasiswa agar menjadi instrument yang baku untuk menyaring masuk mahasiswa.

\section{METODE PENELITIAN}

Jenis penelitian ini yaitu penelitian campuran yang berdasarkan pendekatannya penelitian ini merupakan penelitian kualitatif dan kuantitatif. Model penelitian menggunakan model penelitian pengembangan (Gall, M. D., Gall, J. P., \& Borg, 2006). Penelitian pengembangan yang dilakukan yang bertujuan untuk mengembangkan alat pengukuran tes kompetensi dasar pada ranah kompetensi keperibadian sikap radikalisme.
Pengembangan instrumen pengukuran dilakukan dengan model pengembangan konseptual dan prosedural.

Proses pengembangan instrumen pengukuran sikap radikalisme diawali dengan perumusan indikator melalui telaah teoritis dan expert judgement (Focus Group Discussion), pembuatan kisi-kisi, penentuan bentuk instrumen, kriteria penilaian, diikuti dengan telaah, revisi, uji coba, analisis data dan penyusnan instrumen bentuk akhir beserta panduan dan norma instrumen. FGD dilakukan oleh 5 ahli yang bertugas memberikan masukan dan penilaian terhadap instrumen yang dikembangkan secara kualitas dan 5 ahli dalam segi bahasa.

Penelitian dilaksanakan di Institut Bisnis dan Multimedia asmi pada bulan Maret sampai September 2020. Teknik pengambilan sampel menggunakan purposive sampling terhadap mahasiswa IBM asmi yaitu 156 responden. Analisis data penelitian menggunakan statistik deskrptif untuk menggambarkan kompetensi kepribadian dan analisis faktor untuk memperdalam dimensi sikap radikalisme. Sebelum data dianalisis, peneliti juga melakukan pembuktian validitas dan reliabilitas . Validitas menggunakan analisis factor confirmatory dan reliabilitas mengguakan alpha cronbach (Azwar, 2012).

\section{HASIL DAN PEMBAHASAN}

Tahap awal pengembangan instrumen dengan mengidentifikasi tujuan pengukuran dan perumusan item indikator dilakukan dengan studi teori operasional. Kompetensi radikalisme terdiri dari 5 variabel observasi yaitu pertama agama, keluarga, kepribadian, pandangan politik dan relasi sosial. Konstruksi instrumen awal dibahas berdasarkan temuan penelitian sebelumnya dan kajian teoritis yang telah dikembangkan sebagaimana yang digambarkan pada tabel 1 . Tahap pengujian awal instrumen SR atau Sikap Radikalisme berisikan 45 butir yang terangkum dalam 5 dimensi.

Terdapat 40 butir terbagi dalam 18 indikator berbentuk pernyataan yang bisa dipilih peserta didik sesuai dengan permasalahan yang dialami. 3 butir lainnya berbentuk pertanyaan 
singkat tentang permasalahan yang dihadapi peserta didik. Setelah itu dilakukan kajian FGD mengundang 5 ahli untuk mendiskusikan dan 5 ahli untuk mengkoreksi atau memberi nilai yang dilakukan untuk mengidentifikasi terhadap kebutuhan pengembangan instrumen terkait dengan konten, input dan tata bahasa. Dari diskusi FGD secara kualitatif pengembangan instrumen yang dilakukan untuk mengidentifikasi terhadap kebutuhan pengembangan instrumen pengukuran radikalisme mengembangkan indikator radikalisme menghasilkan gagasan pengembangan instrumen terangkum sebagai berikut:

Ikhsanudin menjelaskan pada bidang pengukuran terkait dengan kisi-kisi dan indikator ditetapkan berdasarkan apa yang dimaksud dengan radikal harus dijelskan secara gamblang. Selain itu secara konsep banyak sekali pandangan berbeda mengenai radikalisme. Secara definisi radikalisme merupakan adanya paham kekerasan dan sebuah paham yang ingin melakukan perubahan dengan jalan kekerasan dan mengadopsi cita-cita dan aspirasi politik sosial agama yang ekstrim menolak atau merusak ekspresi kebebasan dalam masyarakat.

Pandangan Trie Yunita Sari mengenai unsur radikalisme tidak hanya terjadi pada satu agama melainkan supermasi agama mayoritas menyerang agama ninoritas seperti di India terjadi karena ini adanya supermasi agama mayoritas. Definisi radikalisme menjadi hal yang tumpang tindih. Namun hal dapat dikaitkan dengan berbagai jenis kelompok radikal memiliki elemen yang sama. Pertama, semua kelompok radikal memandang masalah serius di masyarakat dari kacamata mereka saja, sehingga berbenturan dengan atruan yang berlaku. Masalah atau keluhan ini berbeda untuk setiap kelompok radikal. Kedua, kelompok radikal sangat tidak puas dengan cara institusi dalam hal ini negara yang saat ini menangani masalah mereka seperti kemiskinan dan timpangnya social ekonomi antara masyarakat miskin dan kaya.

Radikalis mungkin berargumen bahwa lembaga atau negara tidak cukup memperhatikan keluhan. Hal ini menciptakan kepercayaan kelembagaan yang rendah dan persepsi bahwa otoritas tidak sah dapat dijatuhkan dengan jalan kekerasan. Karakteristik penting ketiga dari kelompok radikal adalah mereka menganggap norma dan nilai kelompok mereka sendiri lebih tinggi dari kelompok lain. Hal ini menciptakan perbedaan yang kuat antara masyarakat pada umumnya, yang mungkin menjadi dasar dari penggunaan kekerasan atau radikalisme.

Trie menjelaskan juga karakteristik dari kelompok radikal sangat penting: sebagian besar kelompok seperti itu menganut ideologi yang melegitimasi kekerasan untuk mengatasi keprihatinan mereka, dan kekerasan ini sering diarahkan pada kelompok luar yang dipandang sebagai pelaku yang bertanggung jawab untuk membuat keluhan. Ini paling jelas diartikulasikan dalam penerapan identitas sosial teori radikalisasi, di mana identifikasi dengan in-group dikombinasikan dengan dis-identifikasi dengan out-group terkait dengan penggunaan kekerasan terhadap anggota out-group.

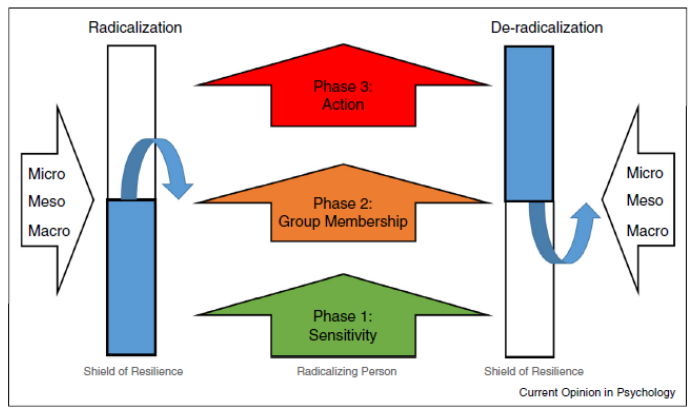

Gambar 1. Fase Perubahan Radikalisme 
Jurnal PAJAR (Pendidikan dan Pengajaran)

Fran Sinatra menjelaskan bahwa kebanyakan orang yang radikal bukan berasal dari dalam diri namun pandangan radikal dapat bersumber dari lingkungan sosial atau keluarga. Sebaliknya, terorisme adalah hasil dari proses radikalisasi dalam langkah-langkah yang dapat terjadi pada orang. Orang yang meradikalisasi membentuk elemen sentral dalam model meradikalisasi. Terdapat tiga fase selama proses radikalisasi: (1) fase sensitivitas, (2) fase keanggotaan kelompok, dan (3) fase tindakan. Radikalisme juga memiliki tingkatan sepereti tingkat mikro (individu), meso (kelompok) dan makro (sosial).

Nyimas memaparkan mengenai radikalisme yang erat kaitanya dengan jarak sosial atau social distance yang mana setiap individu yang radikal memiliki kecendrungan diakibatkan prasangka sosial yang membuat setiap kelompok memiliki definisi diri individu, terutama yang berkaitan dengan tujuan, nilai, dan keyakinan yang mereka pegang dalam domain yang menjadi perhatian seperti panggilan, agama, politik, peran keluarga, peran gender, etnis, dan kepentingan pribadi. Selain itu ada banyak literatur teoritis dan empiris tentang proses-proses yang terlibat dalam membangun rasa identitas pribadi yang mengkonseptualisasikan pembentukan identitas dalam arti dimensi eksplorasi. Dalam paradigma ini, dua hasil potensial memiliki relevansi khusus untuk munculnya identitas teroris: (a) penyitaan otoriter dan (b) difusi tanpa tujuan.

Penyitaan merupakan pengadopsian komitmen tanpa mempertimbangkan alternatif lain, sedangkan difusi mewakili tidak terikat dan terlibat dalam sedikit atau tidak ada eksplorasi sistematis. Status yang diambil alih dan disebarkan berbagi elemen bahwa cita-cita kelompok diadopsi dan diinternalisasi, baik secara aktif atau secara default, tanpa mempertanyakan dan tanpa pertimbangan aktif tentang kemungkinan alternatif. Misalnya, individu yang diklasifikasikan sebagai yang diambil alih atau disebarkan ternyata kurang dewasa secara religius dan secara aktif memahami keyakinan bahwa mereka pada tingkat yang lebih rendah, dibandingkan dengan mereka yang telah menjalani periode eksplorasi aktif dan mengembangkan seperangkat komitmen identitas. Individu dengan pendekatan yang kurang berpikiran terbuka terhadap masalah identitas mungkin lebih mungkin untuk menafsirkan iman mereka secara harfiah daripada secara simbolis. Ada bukti bahwa individu otoriter - terutama mereka yang menganggap diri mereka sebagai "Di luar arus utama" mungkin menjadi ancaman bagi masyarakat karena mereka memiliki kemampuan, visi yang tunggal dan lugas, serta keinginan untuk menarik pengikut dan membentuk kelompok berdasarkan prinsip-prinsip yang merusak.

Agus menambahkan Kelompok radikal memiliki ciri-ciri antara lain; pertama sering mengklaim kebenaran tunggal dan menyesatkan kelompok lain yang tak sependapat. Klaim kebenaran selalu muncul dari kalangan yang seakan-akan mereka adalah Nabi yang tak pernah melakukan kesalahan ma'sum padahal mereka hanya manusia biasa. Klaim kebenaran tidak dapat dibenarkan karena manusia hanya memiliki kebenaran yang relatif dan hanya Tuhan yang tahu kebenaran absolut. Kedua, radikalisme mempersulit agama yang sejatinya samhah (ringan) dengan menganggap ibadah sunnah seakan-akan wajib dan makruh seakan-akan haram.

Radikalisme dicirikan dengan perilaku beragama yang lebih memprioritaskan persoalanpersoalan sekunder dan mengesampingkan yang primer. Ketiga, kelompok radikal kebanyakan berlebihan dalam beragama yang tidak pada tempatnya. Dalam berdakwah mereka mengesampingkan metode gradual yang digunakan oleh Nabi, sehingga dakwah mereka justru membuat umat agama yang masih awam merasa ketakutan dan keberatan.

Pembuatan konten dan development instrumen yaitu dengan menggunakan perencanaan dari yang selanjutnya akan dilakukan tahap uji coba instrumen terhadap mahasiswa sebanyak dua kali dengan analisis validitas konstruk dan reliabilitas nya, selanjutnya diinterpretasikan hasil instrumen yang telah valid dan reliabel. Tujuan pengukuran dan perumusan item indikator dilakukan dengan studi teori 
operasional. Berikut rumusan hasil FGD hasil diskusi dalam FGD: pembahasan pengukuran radikalisme berdasarkan

Tabel 1. Pengembangan Indikator Identifikasi Radikalisme Berdasarkan FGD

\begin{tabular}{|c|c|c|c|}
\hline No. & Dimensi & Definisi Operasional & Indikator \\
\hline 1. & Agama & $\begin{array}{l}\text { Menggambarkan sosok Tuhan } \\
\text { yang penuh penghakim terhadap } \\
\text { manusia yang tidak menjalankan } \\
\text { perintah-Nya dan menganggap } \\
\text { bahwa jihad merupakan perang } \\
\text { suci dan membolehkan tindakan } \\
\text { kekerasan terhadap pihak yang } \\
\text { tidak sepaham. }\end{array}$ & $\begin{array}{l}\text { 1.1. Memiliki pandangan terhadap sosok Tuhan yang penuh } \\
\text { penghakim terhadap manusia yang berdosa } \\
\text { 1.2. Memiliki pandangan bahwa membela agama merupakan perang } \\
\text { suci } \\
\text { 1.3. Memiliki pandangan terhadap agama yang dianut merupakan } \\
\text { agama yang paling benar dan agama lain salah } \\
\text { 1.4. Memperbolehkan menggunakan kekerasan dalam beragama }\end{array}$ \\
\hline 2. & Keluarga & $\begin{array}{l}\text { Lingkungan keluarga tidak terbuka } \\
\text { terhadap perubahan dan tidak } \\
\text { harmonis. Orang tua cenderung } \\
\text { mengajarkan radikalisme kepada } \\
\text { anak untuk diterapkan. }\end{array}$ & $\begin{array}{l}\text { 2.1. Memiliki keluarga yang tidak harmonis } \\
\text { 2.2. Memiliki keluarga yang sangat agamis dan menolak ilmu umum } \\
\text { 2.3. Memiliki keluarga yang tertutup }\end{array}$ \\
\hline 3. & $\begin{array}{l}\text { Kepribadia } \\
\mathrm{n}\end{array}$ & $\begin{array}{l}\text { Berusaha menolak dari dalam diri } \\
\text { terhadap tatanan yang ada. Hal ini } \\
\text { disebabkan oleh peristiwa katalis } \\
\text { negatif pada faktor penentu } \\
\text { psikologis tingkat mikro salah } \\
\text { satunya radikalisasi agama. }\end{array}$ & $\begin{array}{l}\text { 3.1. Memiliki pribadi yang agresif } \\
\text { 3.2. Bersikap intoleran } \\
\text { 3.3. Tidak mau menerima perubahan } \\
\text { 3.4. Memiliki kecenderungan introvert }\end{array}$ \\
\hline 4. & $\begin{array}{l}\text { Pandangan } \\
\text { Politik }\end{array}$ & $\begin{array}{l}\text { Menerapkan intoleransi ekstrim } \\
\text { yang memaksakan kemauan } \\
\text { kepada orang lain atau mencoba } \\
\text { mengubah masyarakat dan politik } \\
\text { sesuai kehendak agama. }\end{array}$ & $\begin{array}{l}\text { 4.1. Memiliki pandangan negara berdasarkan agama } \\
\text { 4.2. Memiliki pandangan tradisional/konservatif } \\
\text { 4.3. Bersikap anti politik barat } \\
\text { 4.4. Mendukung aksi kekerasan untuk perubahan politik }\end{array}$ \\
\hline 5. & $\begin{array}{l}\text { Relasi } \\
\text { Sosial }\end{array}$ & $\begin{array}{l}\text { Mendukung adanya kelompok } \\
\text { orang atau organisasi } \\
\text { kemasyarakatan dengan landasan } \\
\text { yang bertentangan dengan dasar } \\
\text { negara. }\end{array}$ & $\begin{array}{l}\text { 5.1. Mengikuti kegiatan secara berkelanjutan dalam organisasi } \\
\text { tertentu dengan landasan yang tidak sejalan dengan dasar } \\
\text { negara } \\
\text { 5.2. Berorganisasi secara fanatik dan tertutup terhadap organisasi } \\
\text { lain } \\
\text { 5.3. Menyebarluaskan paham organisasi yang menyimpang dari } \\
\text { dasar negara }\end{array}$ \\
\hline
\end{tabular}

Pengembangan instrumen hasil berdasarkan hasil $F G D$ menghasilkan 5 dimensi ukur dikembangkan dan dinilai berdasarkan rater atau uji validitas Aiken yang digambarkan pada tabel 3. Hasil validitas uji rater yang berasal dari 5 narasumber penilai instrumen menghasilkan nilai validitas sebagai berikut:

Tabel 2. Hasil Validitas Aiken

\begin{tabular}{llllll}
\hline Butir & Aiken & Hasil & Butir & Aiken & Hasil \\
\hline B_1 & 0.5 & Tidak Valid & B_21 & 0.75 & Valid \\
B_2 & 0.7 & Valid & B_22 & 0.8 & Valid \\
B_3 & 0.8 & Valid & B_23 & 0.75 & Valid \\
B_4 & 0.55 & Tidak Valid & B_24 & 0.7 & Valid \\
B_5 & 0.8 & Valid & B_25 & 0.8 & Valid \\
B_6 & 0.7 & Valid & B_26 & 0.75 & Valid \\
\hline
\end{tabular}


Jurnal PAJAR (Pendidikan dan Pengajaran)

Volume 5 Nomor 2 Maret 2021 | ISSN Cetak : 2580 - 8435 | ISSN Online : 2614 - 1337

DOI : http://dx.doi.org/10.33578/pir.v5i2.8222

\begin{tabular}{llllll}
\hline B_7 & 0.7 & Valid & B_27 & 0.8 & Valid \\
B_8 & 0.7 & Valid & B_28 & 0.9 & Valid \\
B_9 & 0.75 & Valid & B_29 & 0.8 & Valid \\
B_10 & 0.6 & Tidak Valid & B_30 & 0.75 & Valid \\
B_11 & 0.7 & Valid & B_31 & 0.8 & Valid \\
B_12 & 0.7 & Valid & B_32 & 0.6 & Tidak Valid \\
B_13 & 0.8 & Valid & B_33 & 0.65 & Tidak Valid \\
B_14 & 0.7 & Valid & B_34 & 0.75 & Valid \\
B_15 & 0.8 & Valid & B_35 & 0.7 & Valid \\
B_16 & 0.7 & Valid & B_36 & 0.72 & Valid \\
B_17 & 0.7 & Valid & B_37 & 0.75 & Valid \\
B_18 & 0.7 & Valid & B_38 & 0.77 & Valid \\
B_19 & 0.7 & Valid & B_39 & 0.78 & Valid \\
B_20 & 0.75 & Valid & B_40 & 0.7 & Valid \\
\hline
\end{tabular}

Hasil penilaian rater menunjukan bahwa terdapat 9 item yang nilainya $\leq 0.7$ atau validitas isi Aiken's-V rendah dan harus diperbaiki. Sehingga terdapat 35 item yang lolos akan diuji cobakan untuk mengetahui pembuktian validitas konstrak dan reliabilitasnya. Validitas konstruk digunakan untuk membuktikan korelasi hasil pengukuran butir-butir dalam angket dengan teoritik yang mendasari penyusunan angket. Validitas konstruk penelitian ini menggunakan analisis faktor eksploratori. Analisis faktor dilakukan dengan mengelompokkan data interkorelasi antrar butir. Hasil uji coba instrumen sikap radikalisme dengan jumlah 150 mahasiswa.
Instrumen ini terdapat 35 butir pernyataan yang telah divalidasi oleh ahli.

Pengujian pertama menggunakan Kaiser Meyer Olkin Measure of Sampling (KMO) adalah indeks perbandingan jarak antara koefisien korelasi dan koefisien korelasi parsial. Jika jumlah kuadrat koefisien korelasi parsial di antara semua pasang variabel bernilai kecil dibandingkan dengan jumlah kuadrat koefisien korelasi, maka akan menghasilkan nilai KMO mendekati 1 . Nilai KMO dianggap mencukupi jika lebih dari 0,5 (Banu \& Duraipandian, 2014). Berikut merupakan hasil pengolahan konstrak setelah instrumen diujicobakan kepada mahasiswa IBM asmi:

Tabel 3. KMO and Bartlett's Test

\begin{tabular}{|c|c|c|}
\hline Kaiser-Meyer-Olkin & & 0.629 \\
\hline $\begin{array}{l}\text { Measure of Sampling } \\
\text { Adequacy. }\end{array}$ & & \\
\hline Bartlett's Test of Sphericity & $\begin{array}{l}\text { Approx. } \\
\text { Chi- }\end{array}$ & 1256.212 \\
\hline & $\begin{array}{l}\text { Square } \\
\mathrm{df}\end{array}$ & 595 \\
\hline & Sig. & 0 \\
\hline
\end{tabular}

Hasil hitungan pembuktian validitas KMO terdapat pada tabel 2. Nilai konstruk KMO diketahui sebesar 0.629 menunjukkan bahwa nilai Kaiser Meyer Olkin Measure MSA lebih besar dari 0.5. Dengan demikian persyaratan KMO memenuhi persyaratan sehingga model instrumen setelah analisis faktor dapat dilanjutkan. Signifikansi Bartlett's Test of Sphericity juga memiliki ke akuratan signifikansi tinggi $(\mathrm{p}<0.000)$. 
Tabel 4. Analisis Faktor Angket Instruktur

\begin{tabular}{ccc}
\hline No. Butir & ${\text { Component } \text { Matrix }^{\boldsymbol{a}}}$ & Anti-Image \\
\hline B1 & 0.47 & 0.69 \\
B2 & 0.37 & 0.75 \\
B3 & 0.53 & 0.65 \\
B4 & 0.45 & 0.74 \\
B5 & 0.42 & 0.65 \\
B6 & 0.42 & 0.72 \\
B7 & 0.47 & 0.76 \\
B8 & 0.39 & 0.69 \\
B9 & 0.39 & 0.67 \\
B10 & 0.45 & 0.77 \\
B11 & 0.59 & 0.57 \\
B12 & 0.64 & 0.54 \\
B13 & 0.33 & 0.77 \\
B14 & 0.41 & 0.71 \\
B15 & 0.33 & 0.72 \\
B16 & 0.41 & 0.71 \\
B17 & 0.69 & 0.53 \\
B18 & 0.40 & 0.73 \\
B19 & 0.38 & 0.69 \\
B20 & 0.45 & 0.57 \\
B21 & 0.53 \\
B22 & 0.51 & 0.56 \\
B23 & 0.42 & 0.60 \\
B24 & 0.43 & 0.55 \\
B25 & 0.52 & 0.64 \\
B26 & 0.48 & 0.64 \\
B27 & 0.37 & 0.65 \\
B28 & 0.39 & 0.55 \\
B29 & 0.51 & 0.55 \\
B30 & 0.58 & 0.45 \\
B31 & 0.71 & 0.52 \\
B32 & 0.54 \\
B33 & 0.39 & 0.44 \\
B34 & 0.58 & 0.61 \\
B35 & 0.64 & 0.55 \\
\hline
\end{tabular}

Korelasi anti-image dari 35 butir menunjukan bahwa terdapat butir yang kurang dari $<0.5$ yaitu pada butir 30 dan butir 33 sehingga pada butir tersebut perlu direduksi atau diperbaiki.

Tabel 5. Total Variance Explained

\begin{tabular}{ccrcrrrr}
\hline Component & \multicolumn{3}{c}{ Initial Eigenvalues } & \multicolumn{2}{c}{ Extraction Sums of Squared } & Rotation \\
& Total & $\begin{array}{c}\text { \% of } \\
\text { Lariance }\end{array}$ & $\begin{array}{c}\text { Cumulative } \\
\text { \% }\end{array}$ & Total & $\begin{array}{c}\text { \% of } \\
\text { Variance }\end{array}$ & $\begin{array}{c}\text { Cumulative } \\
\%\end{array}$ & Total \\
\hline 1 & 4.671 & 13.344 & 13.344 & 4.671 & 13.344 & 13.344 & 3.107 \\
2 & 2.491 & 7.116 & 20.460 & 2.491 & 7.116 & 20.460 & 2.880 \\
3 & 1.971 & 5.631 & 26.091 & 1.971 & 5.631 & 26.091 & 2.056 \\
4 & 1.874 & 5.354 & 31.445 & 1.874 & 5.354 & 31.445 & 2.101 \\
\hline
\end{tabular}


Jurnal PAJAR (Pendidikan dan Pengajaran)

Volume 5 Nomor 2 Maret 2021 | ISSN Cetak : 2580 - 8435 | ISSN Online : 2614 - 1337

DOI : http://dx.doi.org/10.33578/pir.v5i2.8222

\begin{tabular}{cccccccc}
\hline 5 & 1.788 & 5.109 & 36.554 & 1.788 & 5.109 & 36.554 & 1.947 \\
6 & 1.503 & 4.293 & 40.847 & 1.503 & 4.293 & 40.847 & 2.728 \\
7 & 1.437 & 4.105 & 44.953 & 1.437 & 4.105 & 44.953 & 2.673 \\
8 & 1.344 & 3.839 & 48.792 & 1.344 & 3.839 & 48.792 & 1.797 \\
9 & 1.292 & 3.690 & 52.482 & 1.292 & 3.690 & 52.482 & 2.020 \\
10 & 1.197 & 3.421 & 55.902 & 1.197 & 3.421 & 55.902 & 2.370 \\
11 & 1.148 & 3.279 & 59.181 & 1.148 & 3.279 & 59.181 & 1.639 \\
12 & 1.081 & 3.090 & 62.271 & 1.081 & 3.090 & 62.271 & 1.565 \\
13 & 1.064 & 3.041 & 65.312 & 1.064 & 3.041 & 65.312 & 1.335
\end{tabular}

Extraction Method: Principal Component Analysis.

a. When components are correlated, sums of squared loadings cannot be added to obtain a total variance.

Selanjutnya untuk melihat seberapa banyak komponen yang terbentuk dari 35 butir pernyataan dapat dilihat pada Initial Eigenvalues $>1.0$. Terdapat 13 komponen yang terbentuk dari 35 butir instrumen. Sehingga yang awalnya instrumen memiliki 18 dimensi menjadi 13 dimensi.

Selain valid, hendaknya suatu instrumen juga reliabel. Suatu instrumen dikatakan reliabel jika instrumen tersebut dapat secara konsisten mengukur apa yang ingin diukur. Reliabilitas atau keandalan merupakan koefisien yang menunjukan tingkat keajegan atau konsistensi hasil pengukuran suatu tes(Rahmat Syah \& Istiana Hermawati, 2018) (Mardapi et al., 2015). Tingkat keajegan suatu instrumen ditentukan berdasarkan besarnya koefisien reliabilitas yang dimiliki. Standar reliabilitas minimum yang digunakan adalah 0.7. Dalam penelitian ini, estimasi reliabilitas konsistensi internal dengan formula Alpha Cronbach untuk lembar angket. Reliabilitas hasil uji coba dengan responden instruktur dan peserta pelatihan ditunjukan dalam Tabel 6 .

Tabel 6. Hasil Pembuktian Reliabilitas

\begin{tabular}{cccc}
\hline No & \multicolumn{2}{c}{ Item-Total Statistics } & \\
Mean & Variance & $\begin{array}{c}\text { Cronbach's } \\
\text { Alpha }\end{array}$ \\
\hline B_1 & 64.3052 & 108.841 & 0.747 \\
B_2 & 64.4481 & 113.491 & 0.756 \\
B_3 & 65.2727 & 115.363 & 0.754 \\
B_4 & 65.2078 & 114.741 & 0.753 \\
B_5 & 65.1753 & 115.322 & 0.754 \\
B_6 & 64.9286 & 114.459 & 0.757 \\
B_7 & 63.9481 & 116.795 & 0.759 \\
B_8 & 64.3636 & 115.135 & 0.757 \\
B_9 & 64.9675 & 110.633 & 0.749 \\
B_10 & 64.8377 & 113.392 & 0.757 \\
B_11 & 64.0909 & 114.410 & 0.758 \\
B_12 & 64.8117 & 112.768 & 0.757 \\
B_13 & 63.8052 & 116.119 & 0.759 \\
B_14 & 64.1558 & 111.740 & 0.754 \\
B_15 & 64.2468 & 115.285 & 0.757 \\
B_16 & 64.1753 & 112.642 & 0.755 \\
\hline
\end{tabular}


Jurnal PAJAR (Pendidikan dan Pengajaran)

Volume 5 Nomor 2 Maret 2021 | ISSN Cetak : 2580 - 8435| ISSN Online : 2614 - 1337

DOI : http://dx.doi.org/10.33578/pir.v5i2.8222

\begin{tabular}{llll}
\hline B_17 & 64.0065 & 110.085 & 0.750 \\
B_18 & 64.1623 & 113.248 & 0.759 \\
B_19 & 64.3247 & 109.580 & 0.749 \\
B_20 & 64.3636 & 109.723 & 0.747 \\
B_21 & 64.5714 & 109.057 & 0.745 \\
B_22 & 64.8571 & 111.287 & 0.749 \\
B_23 & 63.4610 & 113.126 & 0.757 \\
B_24 & 63.8377 & 106.908 & 0.742 \\
B_25 & 64.5584 & 108.693 & 0.743 \\
B_26 & 64.6429 & 110.244 & 0.748 \\
B_27 & 63.8506 & 109.213 & 0.750 \\
B_28 & 64.0779 & 108.464 & 0.745 \\
B_29 & 65.0130 & 110.497 & 0.744 \\
B_30 & 64.8312 & 108.873 & 0.740 \\
B_31 & 64.5000 & 111.036 & 0.749 \\
B_32 & 64.6169 & 104.186 & 0.738 \\
B_33 & 65.0974 & 109.749 & 0.742 \\
B_34 & 65.1623 & 113.653 & 0.752 \\
B_35 & 64.7922 & 109.342 & 0.745 \\
\hline
\end{tabular}

Berdasarkan hasil dari perhitungan dengan Alpha Cronbach di atas dapat diketahui bahwa kuesioner instruktur termasuk dalam tingkat reliabel dan kuesioner peserta didik juga termasuk dalam tingkat reliabel. Keandalan skala yang meningkat secara signifikan menggambarka nilai reliabilitas yang diinginkan $\geq 0.70$ artinya dapat disimpulkan bahwa butir tersebut reliabel atau konsisten. Reliabilitas menurut Yusup et al. (2018) bermakna konsistensi, yaitu pengukuran oleh satu instrumen yang dilakukan berkali-kali maka hasilnya sama, atau tidak banyak perbedaan yang berarti (dalam satu pengukuran akan selalu terdapat perbedaan hasil walaupun kecil dan bisa ditoleransi perbedaannya).

Pengembangan instrumen tes kompetensi kepribadian dalam mengidentifikasi sikap radikalisme meruapakan tes yang menggambarkan sikap individu yang terpapar paham radikalis yang didefinisikan sebagai paham di mana seseorang atau kelompok mengadopsi cita-cita dan aspirasi politik, sosial, atau agama yang secara bertahap ekstrim yang pertama menolak atau merusak tatanan negara (status quo), kedua menolak atau merusak ide-ide kontemporer dan ekspresi kebebasan berbangsa (Wilner \& Dubouloz, 2010).
Pengembangan instrumen identifikasi sikap radikalisme ini didasari oleh pengukuran karakteristik sesuai dengan kaidah pengukuran (Azwar, 2013). Verbeke (1994) juga menjelaskan karakter pribadi telah terbukti dapat memprediksi kemampuan individu dalam bidang softskil. Radikalisme dalam penelitian ini juga berfokus pada radikalisme yang terkait dengan prilaku keagamaan individu yang bertentangan dengan hukum dan norma yang berlaku. Ghosh et al., (2017) menjelaskan bahwa pemahaman agama yang salah merupakan salah satu faktor yang dijadikan pemicu individu menjadi radikal. Indikator yang dikembangkan hasil dari pengambilan data secara $F G D$ menggambarkan bahwa penggambaran radikalisme haruslah tepat karena radikal sendiri memiliki makna yang luas. Secara etimologis, kata radikal sesungguhnya netral. Radikalis, kata sifat ini berasal dari bahasa latin, radix atau radici. Menurut Concise Oxford English dictionary (2012), istilah radikal berarti 'akar', 'sumber', atau 'asal-mula'. Dimaknai lebih luas, istilah radikal mengacu pada hal-hal mendasar, prinsip-prinsip fundamental, pokok soal, dan esensial atas bermacam gejala, atau juga bisa bermakna "tidak biasanya" (unconventional). 


\section{SIMPULAN DAN REKOMENDASI}

Hasil FGD menggambarkan bahwa identifikasi sikap radikal pada penelitian ini digambarkan dalam lima dimensi pertama agama, keluarga, kepribadian, pandangan politik dan relasi sosial. Dimensi agama menjelaskan bahwa radikalis menggambarkan sosok Tuhan yang penuh penghakim terhadap manusia yang tidak menjalankan perintah-Nya dan menganggap bahwa jihad merupakan perang suci dan membolehkan tindakan kekerasan terhadap pihak yang tidak sepaham. Dimensi keluarga radikalis memiliki gambaran keluarga yang tidak terbuka terhadap perubahan dan tidak harmonis. Orang tua cenderung mengajarkan radikalisme kepada anak untuk diterapkan. Dimensi kepribadian berusaha menolak dari dalam diri terhadap tatanan yang ada. Hal ini disebabkan oleh peristiwa katalis negatif pada faktor penentu psikologis tingkat mikro salah satunya radikalisasi agama. Dimensi Pandangan Politik Menerapkan intoleransi ekstrim yang memaksakan kemauan kepada orang lain atau mencoba mengubah masyarakat dan politik sesuai kehendak agama. Dimensi relasi Sosial Mendukung adanya kelompok orang atau organisasi kemasyarakatan dengan landasan yang bertentangan dengan dasar negara.

Radikalisme yang menyebabkan indikasi kekerasan merupakan musuh bersama, sehingga perlu ada strategi khusus dalam hal ini untuk mengidentifikasi sikap tersebut. Rekomendasi dalam hal pengembangan instrumen tes kompetensi kepribadian untuk mengidentifikasi sikap radikalisme yang menghasilkan instrumen yang dapat mengidentifikasi sikap radikalisme sehingga pihak instansi dapat memberikan pencegahan agar tidak terjadinya penyebaran paham radikalsime. Instrumen yang dikembangkan dalam dalam penelitian ini perlu uji coba lebih lanjut karena selain pengukuran sikap radikalisme yang mendalam diperlukan pendekatan multikultural untuk mengembangan instrumen yang valid dan reliable. Konsep multikultural ini lebih ditekankan pada setiap proses di dalam sikap radikalisme. Selain itu hasil analisis pengembangan indikator kompetensi radikalisme memberikan gambaran yang utuh untuk melihat sikap radikalisme sehingga perlu dilakukan pengukuran presentase.

\section{DAFTAR PUSTAKA}

Amin, K. (2008). Muslim Western Scholarship of Hadith and Western Scholar Reaction: A Study on Fuat Sezgin's Approach to Hadith Scholarship. Al-Jami'ah: Journal of Islamic Studies. https://doi.org/10.14421/ajis.2008.462.25 3-277

Azwar, S. (2013). KUALITAS TES POTENSI AKADEMIK VERSI 07A. Jurnal Penelitian Dan Evaluasi Pendidikan. https://doi.org/10.21831/PEP.V12I2.1429

Banu, A. R., \& Duraipandian, K. (2014). Development of an Instrument To Measure Work Life Balance of It Professionals in Chennai. International Journal of Management.

BBC NEWS Indonesia. (2018). Dari Mako Brimob sampai Poltabes Surabaya: Satu minggu Penuh Teror. www.bbc.com/indonesia/amp/trensosial44108? espv=1

BPS, BKKBN, Kemenkes, U. (2012). Survei Demografi dan Kesehatan Indonesi 2012 Kesehatan Reproduksi Remaja. BKKBN.

Concise Oxford English dictionary. (2012). Choice Reviews Online. https://doi.org/10.5860/choice.49-2393

Conway, M. (2017). Determining the role of the internet in violent extremism and terrorism: Six suggestions for progressing research. Studies in Conflict and Terrorism.

https://doi.org/10.1080/1057610X.2016.1 157408

Ghosh, R., Chan, W. Y. A., Manuel, A., \& Dilimulati, M. (2017). Can education counter violent religious extremism? Canadian Foreign Policy Journal. https://doi.org/10.1080/11926422.2016.11 65713

Hasan, N. (2012). Education, Young Islamists and Integrated Islamic Schools in Indonesia. Studia Islamika. https://doi.org/10.15408/sdi.v19i1.370 
Jurnal PAJAR (Pendidikan dan Pengajaran)

Volume 5 Nomor 2 Maret 2021 | ISSN Cetak : 2580 - 8435| ISSN Online : 2614 - 1337

DOI : http://dx.doi.org/10.33578/pjr.v5i2.8222

Honig, O., \& Yahel, I. (2017). A Fifth Wave of Terrorism? The Emergence of Terrorist Semi-States. Terrorism and Political Violence.

https://doi.org/10.1080/09546553.2017.13 30201

Mardapi, D., Hadi, S., \& Retnawati, H. (2015). MENENTUKAN KRITERIA KETUNTASAN MINIMAL BERBASIS PESERTA DIDIK. Jurnal Penelitian Dan Evaluasi Pendidikan. https://doi.org/10.21831/pep.v19i1.4553

Nurish, A. (2020). The Myth of Religious "Radicalism." Al-Albab. https://doi.org/10.24260/alalbab.v9i1.154 6

Rahmat Syah, \& Istiana Hermawati. (2018). EVALUATION OF CHILDREN'S
PERFORMANCE ASSESSMENT IN
PRESCHOOL.

Verbeke, W. (1994). Personality characteristics that predict effective performance of sales people. Scandinavian Journal of Management.

https://doi.org/10.1016/09565221(94)90036-1

Wilner, A. S., \& Dubouloz, C. J. (2010). Homegrown terrorism and transformative learning: An interdisciplinary approach to understanding radicalization. Global Change, Peace and Security. https://doi.org/10.1080/147811509034879 56

Wirawan, J. (2017). Akan repot' jika hanya andalkan Polri lawan terorisme siber. $B B C$ Indonesia. https://www.bbc.com/indonesia/amp/indo nesia-40571283? espv=1

Yusup, F., Studi, P., Biologi, T., Islam, U., \& Antasari, N. (2018). Uji Validitas Dan Reliabilitas. Jurnal Tarbiyah: Jurnal Ilmiah Kependidikan. 